\title{
O umowach prawnorolnych
}

1. Uczczenie dokonań Szanownego Jubilata, wielce zasłużonego dla rozwoju teorii prawa rolnego ${ }^{1}$, wymaga starannego wyboru tematu rozważań, korespondującego z profilem Jego zainteresowań. I tu chciałbym przywołać znamienny pogląd Profesora Romana Budzinowskiego na temat umiejscowienia prawa rolnego na tle podziału systemu prawa na prawo prywatne i publiczne. Zdaniem Jubilata prawo rolne mieści się w części w prawie prywatnym, a w części - w prawie publicznym. I co istotne, „dopiero łączne ujęcie regulacji z zakresu prawa cywilnego oraz prawa administracyjnego dotyczących rolnictwa stało się impulsem do wyodrębnienia prawa rolnego"2. Zajmując się studiowaniem problemów wzajemnych relacji pomiędzy instytucjami prawa prywatnego a regulacjami publiczno-prawnymi ${ }^{3}$, chciałbym zwrócić uwagę na instytucje czy mechanizmy prawne stosowane w regulacjach prawa rolnego o charakterze zarówno prywatno-, jak i publicznoprawnym. Takim mechanizmem są moim zdaniem umowy prawnorolne. Koncepcja i konstrukcja instytucji umów prawnorolnych dotyczących działalności rolniczej, będących umowami prawa prywatnego, ale także przybierających postać prawnej formy działalności administracji publicznej, wzmacniają tezę o integralności i odrębności prawa rolnego. Terminem „umowy prawnorolne” proponuję określać wszelkie konsen-

* Uniwersytet w Białymstoku.

${ }^{1}$ R. Budzinowski, Problemy ogólne prawa rolnego. Przemiany podstaw legislacyjnych i koncepcji doktrynalnych, Poznań 2008.

2 R. Budzinowski, Prawo rolne i inne dziedziny prawa, w: P. Czechowski (red.), Prawo rolne, Warszawa 2019, s. 28, 36-42.

3 S. Prutis, Instytucje podstawowe prawa prywatnego (w opozycji do regulacji prawa publicznego), Białystok 2018. 
sualne czynności prawne służące realizacji celów polityki rolnej (aspekt funkcjonalny), mające charakter i konstrukcję umów cywilnoprawnych, ale także konstrukcję umów administracyjnych, będących obligatoryjną formą działania podmiotu administrującego.

2. Rozważając relacje i porównania między instytucjami prawa prywatnego i publicznego, dokonałem porównań między umową cywilnoprawną a kategorią „niewładczych” działań administracji ${ }^{4}$, mając na uwadze powszechnie akceptowaną $\mathrm{w}$ doktrynie propozycję katalogu prawnych form działania administracji, a wśród nich umowy ${ }^{5}$. O ile wszakże na temat umów cywilnoprawnych napisano już wiele, o tyle umów administracyjnych cywiliści nie dostrzegają, traktując je jako coś ubocznego - swoiste „ciało obce". Administratywiści również traktowali umowy jako nietypową formę działania administracji, ograniczając się jedynie do zgłaszania propozycji o charakterze ogólnym. Stan dyskusji prowadzonej przez administratywistów zmierzających do wyróżnienia analogicznej do umowy cywilnoprawnej formy działania przedstawił Jan Boć, w 5. tomie Systemu Prawa Administracyjnego ${ }^{6}$. Autor zwrócił uwagę, że: „Brak dokładnej, choćby najogólniej zarysowanej systematyki form konsensualnych [działania administracji] wpycha normodawcę w twory wieloznaczeniowe nasycone elementami destrukcyjnymi wobec klarowności systemu prawa, nie daje podstaw doktrynalnego doskonalenia, utrudnia orzecznictwo, mąci sprawność i skuteczność działań egzekucyjnych. Właśnie istnienie tego typu zagrożeń powinno budować przekonanie o celowości takich ujęć w nauce, które deprecjonują podobne niedogodności"7. Zdaniem J. Bocia trzeba by wyróżnić taką formę, która objęłaby wszystkie niecywilnoprawne formy konsensualne, podejmowane przez podmioty z obrębu administracji publicznej. Autor dostrzega potrzebę „kategorycznego wyodrębnienia pojęcia umowy publicznoprawnej, na którą składałyby się trzy postacie konsensualne, a to a) postać umowy administracyjnej, zawieranej przez organ administracyjny z podmiotem zewnętrznym wobec struktury administracji publicznej, b) postać porozumienia - formy konsensualnej podejmowanej przez podmioty z obrębu administracji pu-

${ }^{4}$ Ibidem, s. 259 i n.

${ }_{5}^{5}$ Pierwsze monograficzne opracowanie na ten temat: J. Starościak, Prawne formy działania administracji, Warszawa 1957; por. także podręcznik: idem, Prawo administracyjne, Warszawa 1977.

6 J. Boć, Działalność konsensualna (dwustronna i wielostronna), w: A. Błaś, J. Boć, M. Stahl, K.M. Ziemski, System Prawa Administracyjnego, t. 5: Prawne formy działania administracji, Warszawa 2013, s. 277 i n.

${ }^{7}$ Ibidem, s. 277. 
blicznej, c) postać ugody jako formy zawieranej przez podmioty zewnętrzne pod kontrolą organu administracyjnego"8. Propozycję tę autor uznaje za logiczny układ spinający wszystkie części i cząstki normowane prawem administracyjnym w sferze zachowań konsensualnych mających znaczenie publicznoprawne.

3. W rozważaniach na temat relacji między instytucjami prawa prywatnego i publicznego, prowadzonych w monografii z 2018 r., uznałem słuszność propozycji J. Bocia co do potrzeby i zasadności wyodrębnienia instytucji umowy administracyjnej z szerszej kategorii umowy publicznoprawnej. Milcząco zakładając różnice konstrukcyjne obu typów umów, nie podjąłem się jednak pogłębienia refleksji na temat odmienności umowy cywilnoprawnej (prywatnoprawnej) i administracyjnej (publicznoprawnej). To ówczesne zaniedbanie nie dawało mi spokoju, więc pomimo statusu emerytowanego już profesora brak ten uzupełniłem, rozważając problem rodzajów i charakteru umów stosowanych poza sferą prawa prywatnego.

Okazało się, że w systemie prawa funkcjonują umowy wykraczające poza typowy zestaw modelowych cech umowy cywilnoprawnej, stanowiącej swobodny konsens równorzędnych, autonomicznych podmiotów, zawierany w celu realizacji ich prywatnych interesów. Oczywiście typologia umów stosowanych poza sferą prawa prywatnego nie może mieć jednolitego charakteru, ze względu na odmienne kryteria i cechy danego typu umowy ${ }^{9}$.

Podjęte rozważania miały głównie na celu wyjaśnienie charakteru i specyficznych cech umowy administracyjnej. I właśnie umowa administracyjna, będąca konsensualną prawną formą działania administracji publicznej, wykazuje najdalej idące odmienności. O ile umowa cywilna jest naturalnym mechanizmem stosowania przepisów skonstruowanych według cywilnoprawnej metody regulacji, o tyle umowa administracyjna jest mechanizmem stosowania przepisów natury administracyjnoprawnej, przyznających organowi administracji kompetencję (a więc uprawnienie i obowiązek) realizacji zadań publicznych. Umowa w tym modelu polega na konsensie pomiędzy autonomicznym podmiotem prawa prywatnego a podmiotem prawa publicznego działającym z woli ustawodawcy i realizującym cele publiczne. Konstrukcyjna modyfikacja modelu umowy administracyjnej polega na tym, że przy zachowaniu formalnej równorzędności stron odmiennie niż w umowie cywilnej ukształtowane zostały reguły dotyczące swobody stron

${ }^{8}$ Ibidem, s. 278.

9 S. Prutis, Typologia umów stosowanych poza sfera prawa prywatnego, w: A. Niewiadomski, K. Marciniuk, P. Litwiniuk (red.), Z zagadnień systemu prawa. Księga Jubileuszowa Profesora Pawta Czechowskiego, Warszawa 2021, s. 705-737. 
w kontraktowaniu, zarówno jeśli chodzi o swobodę zawarcia umowy, jak i o swobodę kształtowania jej treści, a szczególnie reguły jej wykonania, które zostały ustalone, i to drobiazgowo, przez ustawodawcę. Okazało się zatem, że każda z metod regulacji prawnej dysponuje niejako własnym, odmiennym modelowo typem umowy ${ }^{10}$.

Odmienny typ umów stosowanych poza sferą prawa prywatnego stanowi także swoista para umów procesowych, jakimi są ugoda sądowa i ugoda administracyjna. Tu też można powiedzieć, że każda metoda regulacji prawnej dysponuje własną, konsensualną formą załatwiania toczących się sporów. Specyfiką konstrukcyjną ugody procesowej jest okoliczność, że jest to ugodowy konsens stron, wymagający dla swojej skuteczności akceptacji organu prowadzącego postępowanie w spornej sprawie; bez takiej akceptacji konsens stron nie wywołuje skutków ani procesowych, ani materialnoprawnych ${ }^{11}$.

W sytuacji uznania prawa pracy za samodzielną gałąź prawa również umowę o pracę należy wyróżnić jako odrębny typ umowy. Umowa ta ma rodowód cywilistyczny i zachowuje „odpowiednie” związki z regulacją Kodeksu cywilnego, lecz jej wyodrębnienie wynika z tego, że jest to jedyna umowa, która stanowi podstawę stosunku pracy, a jednocześnie zapewnia uzyskanie statusu pracowniczego, regulowanego także przepisami natury publicznoprawnej z dziedziny prawa pracy i ubezpieczeń społecznych ${ }^{12}$.

4. Do umów stosowanych poza sferą prawa prywatnego zaliczyłem także umowy prawnorolne, z tym że specyfika tych umów ma charakter funkcjonalny. Umowy prawnorolne przybierają konstrukcyjnie postać umowy cywilnoprawnej lub administracyjnej; od klasycznego modelu tych umów umowy prawnorolne odróżnia cel regulacji prawnej, jaki ustawodawca chce osiągnąć poprzez odpowiednie ukształtowanie warunków zawarcia i treść umowy. Specyficzna regulacja prawna służy realizacji celów polityki rolnej państwa, aktualnie Wspólnej Polityki Rolnej. Specyfika prawnorolna jest konsekwencją ingerencji ustawodawcy w systemy swobodnego kontraktowania, aby zabezpieczyć także realizację interesu publicznego.

W przygotowanym wówczas opracowaniu umowy prawnorolne stanowiły jedynie element szerszych rozważań, choć niezwykle istotnych, bo podjąłem tam problemy modelowej konstrukcji umowy administracyjnej oraz normatywnej regulacji takich umów w dziedzinie prawa rolnego w postaci umów przyznawania pomocy z Europejskiego Funduszu Rolnego na rzecz Rozwoju Obszarów Wiejskich. Przyznaję, że to właśnie regulacja prawna

${ }^{10}$ S. Prutis, Typologia umów..., s. 720 i n.

${ }^{11}$ Ibidem, s. 737.

${ }^{12}$ Ibidem, s. 712 i n. 
umów przyznawania pomocy dla realizacji PROW, ze względu na ich odmienność od standardów umowy cywilnoprawnej, zdecydowała o moim zainteresowaniu modelem umowy administracyjnej oraz podjęciu analizy treści umów przyznawania pomocy. Po dwóch latach przemyśleń chciałbym w niniejszym opracowaniu uporządkować i pogłębić rozważania na temat umów prawnorolnych. Jak wspomniałem, umowy prawnorolne, gdy chodzi o model czy podstawę konstrukcyjną, przybierają postać umowy cywilnoprawnej lub umowy administracyjnej. O ile ta pierwsza nie wymaga wyjaśnień, o tyle szersze omówienie konstrukcji umowy administracyjnej jest wręcz niezbędne.

5. Odwołując się do poglądów administratywistów, w szczególności do koncepcji J. Bocia, można stwierdzić, że umowa administracyjna jest rodzajem umowy wyodrębnianym według dwóch kryteriów: podmiotowego (organ administracji publicznej i podmiot zewnętrzny) oraz funkcjonalnego (w celu realizacji publicznych zadań organu, a szerzej - podmiotu administrującego). Kryteria te są wystarczające do wyróżnienia kategorii „umowy w administracji”, rozumianej jako wyeksponowanie nie władczej, lecz konsensualnej formy w administracji, ujętej przedmiotowo, jako zorganizowana działalność legitymowanych podmiotów, podjętej w celu realizacji ustawowo określonych zadań publicznych. Nie są jednak adekwatne do wyodrębnienia kategorii umowy administracyjnej (publicznoprawnej) jako umowy odmiennej konstrukcyjnie od kategorii umowy cywilnoprawnej (prywatnoprawnej). Trzeba tu wyjaśnić, że realizacja zadań administracji przez podmioty administrujące wymaga od nich także uczestnictwa w klasycznym obrocie cywilnoprawnym (umowy sprzedaży, najmu, ubezpieczenia). Jeżeli podmioty administrujące występują w charakterze stron umów cywilnoprawnych, to służą im, tak jak ich kontrahentom, wszelkie atrybuty podmiotów prywatnoprawnych. Podobnie w umowach o pracę podmioty administrujące mają status pracodawcy (zakładu pracy); umów o pracę z urzędnikami nie zalicza się do kategorii prawnych form działania administracji. Również cywilnoprawną konstrukcję mają umowy zawierane w celu organizacji wykonania blankietowo określonych zadań administracji publicznej. Przykładem może być - w ramach realizacji zadania przeciwdziałania bezrobociu - zawieranie umów z wyspecjalizowanymi firmami w sprawie prowadzenia szkoleń przygotowujących do wykonywania zawodu. Wszystkie te umowy są to umowy cywilnoprawne zawierane w administracji. Termin „umowa administracyjna” proponuję zarezerwować dla takich umów, które cechują się odmiennością konstrukcyjną od klasycznej umowy cywilnoprawnej. 
Wyjaśnienie odmienności konstrukcyjnej obu umów wymaga odwołania się do koncepcji metod regulacji prawnej, a ściślej - do różnic między nimi. Jak wiadomo, metoda cywilnoprawna opiera się na autonomii podmiotów, czego konsekwencją jest równorzędność podmiotów i swoboda kontraktowania. Metoda administracyjna opiera się na kompetencji organu administracji, konsekwencją czego jest prawo i obowiązek działania organu, a skuteczność działania zapewnia nadrzędność organu i podporządkowanie strony w stosunku administracyjnoprawnym ${ }^{13}$. Pytanie zasadnicze brzmi: jakie są konsekwencje zastosowania - z woli ustawodawcy - umowy, będącej naturalnym mechanizmem prawa prywatnego, do stosunku administracyjnoprawnego, opartego modelowo na nierównorzędności podmiotów? Moim zdaniem mechanizm zmian konstrukcyjnych, czyli „,przekształcenia” modelu umowy cywilnej w umowę administracyjną, można opisać w następujący sposób.

Przypominam, że umową można nazywać (i jest to niezbędne minimum) konsens równorzędnych, prawnie odrębnych podmiotów. Aby zostać stroną umowy, organ administracji musi „zejść z piedestału” nadrzędności i stać się równorzędną stroną wobec swego kontrahenta; to jest swoiste odejście od standardu metody administracyjnej. Równorzędność podmiotów nie oznacza jednak tożsamości ich statusu. Podmiot prawa prywatnego tworzy i kształtuje treść relacji prawnych na mocy przysługującej mu autonomii woli, a będąc podmiotem autonomicznym, działa w swoim prywatnym interesie. Organ administracyjny nie jest podmiotem autonomicznym - ,panem swojej woli”, gdyż zgodnie z zasadą legalizmu działa na mocy przyznanej przez ustawodawcę kompetencji, realizując powierzone mu zadania publiczne. Dopuszczenie do umowy podmiotu niewyposażonego w autonomię woli jest także swoistym odejściem od standardu metody cywilnoprawnej. W jednej z konstatacji na temat metod regulacji prawnej wyraziłem pogląd: „Bez autonomii woli podmiotów nie ma mechanizmu działania prawa cywilnego, podobnie - bez kompetencji organu państwowego nie można mówić o metodzie administracyjnej (publicznoprawnej)"14. Dokonana analiza prowadzi natomiast do spostrzeżenia, że umowa w tym przypadku polega na konsensie między autonomicznym podmiotem prawa prywatnego a podmiotem prawa publicznego, będącym wyrazicielem i wykonawcą woli ustawodawcy. Mamy zatem do czynienia z sytuacją, gdy przy zachowaniu formalnej równorzędności stron odmiennie niż w klasycznej umowie kształtują się modelowe cechy swobody kontraktowania. Przyznanie organowi kompetencji realizacji

${ }^{13}$ S. Prutis, Instytucje podstawowe prawa prywatnego..., s. 62 i n.

${ }^{14}$ Ibidem, s. 63. 
powierzonego zadania oznacza, jak wiadomo, uprawnienie, ale i obowiązek jego realizacji w nakazanym trybie. Skoro organ ma obowiązek działania, nie można mówić o swobodzie decydowania w kwestii samego zawarcia umowy; wybór kontrahenta jest również ograniczony, ponieważ przepisy dość precyzyjnie określają warunki, które ma spełniać potencjalny kontrahent (najczęściej nazywany beneficjentem); określony jest rodzaj zadania, determinujący tym samym treść umowy, a co najważniejsze - ustawodawca określa mechanizm prawny zapewniający realizację zadania. Tak uregulowana umowa, zastosowana z woli ustawodawcy do realizacji zadań publicznych, mająca podstawę w ustawowym przepisie prawa administracyjnego, jest prawną formą działania administracji, dlatego proponuję ją nazwać umową administracyjną. Umowy w sferze administracji, gdy są zawierane w sposób swobodny, z woli stron, niejako przy okazji administrowania, mają charakter cywilnoprawny. Umowę nakazaną przepisem ustawowym, zawieraną „Z woli ustawodawcy w celu wykonania kompetencji administrowania”, będącą obligatoryjną formą działania podmiotu administrującego, proponuję określać jako umowę administracyjną. Uzasadnieniem tej propozycji jest wskazanie na odmienności konstrukcyjne obu metod regulacji prawnej oraz jej przydatność do ustalania typologii umów w systemie prawnym, jak również do interpretacji regulacji prawnej umów o przyznawaniu pomocy z Europejskiego Funduszu Rolnego na rzecz Rozwoju Obszarów Wiejskich, które moim zdaniem należy kwalifikować jako umowy prawnorolne, należące kategorii umów administracyjnych.

6. Uzyskanie członkostwa w Unii Europejskiej oznaczało objęcie naszego rolnictwa programami Wspólnej Polityki Rolnej (WPR); właśnie programy rozwoju obszarów wiejskich (PROW) są jednym z filarów WPR ${ }^{15}$. PROW jest dokumentem przygotowywanym przez każde z państw członkowskich na 7-letni okres programowania, a jego wdrażanie jest przedmiotem specjalnej regulacji prawnej prawa unijnego oraz krajowego. W Polsce głównym, obowiązującym źródłem prawa krajowego w zakresie polityki rozwoju obszarów wiejskich jest ustawa z 20 lutego 2015 r. o wspieraniu rozwoju obszarów wiejskich z udziałem Europejskiego Funduszu Rolnego na rzecz Rozwoju Obszarów Wiejskich na lata 2014-2020 ${ }^{16}$. Ustawa ta określa zadania oraz właściwości organów i jednostek organizacyjnych, warunki

${ }^{15}$ Syntetycznie na temat filarów WPR: D. Milanowska, Wspólna Polityka Rolna, w: S. Prutis (red.), Wielka Encyklopedia Prawa, t. VIII: Prawo rolne i żywnościowe, Warszawa 2015, s. 214-215.

${ }^{16}$ Ustawa z 20 lutego 2015 r. o wspieraniu rozwoju obszarów wiejskich z udziałem Europejskiego Funduszu Rolnego na rzecz Rozwoju Obszarów Wiejskich na lata 2014-2020 (t.j. Dz. U. z 2021 r., poz. 182). 
i tryb przyznawania, wypłaty oraz zasady zwracania pomocy finansowej w ramach działań objętych PROW. Zadania PROW, struktury organizacyjne i mechanizmy prawne ich wdrażania stanowią rozbudowaną machinę organizacyjno-prawną ${ }^{17}$. Wsparcie rozwoju obszarów wiejskich polega głównie na pomocy finansowej, a jej zakres przedmiotowy obejmuje określone ustawą działania (14 rodzajów) i poddziałania (łącznie 30 rodzajów) ${ }^{18}$. Przykładowo można wskazać następujące rodzaje działań: usługi z zakresu zarządzania gospodarstwem, wsparcie inwestycji w gospodarstwach rolnych, wsparcie inwestycyjne w prowadzeniu działalności pozarolniczej, tworzenie grup producentów i organizacji producentów, działania rolno-środowiskowo-klimatyczne, rolnictwo ekologiczne, płatności dla obszarów z ograniczeniami naturalnymi.

O wyborze prawnego mechanizmu przyznawania konkretnego rodzaju wsparcia zdecydował sam ustawodawca, określając bezpośrednio w ustawie działania, w których pomoc jest przyznawana w drodze decyzji (art. 26 ust. 1) oraz takie, w których pomoc jest przyznawana na podstawie umowy (art. 34 ust. 1). Ocena trafności doboru przez ustawodawcę instrumentu decyzja czy umowa - adekwatnego do realizacji poszczególnych działań i podziałań ${ }^{19}$ wymaga tak naprawdę badań empirycznych. Można jednak powiedzieć, że decyzja powinna być stosowana, gdy udzielana pomoc przyjmuje postać działań schematycznych, szablonowych; umowa - gdy potrzebne jest zindywidualizowanie warunków czy sposobów wykorzystania pomocy do realizacji złożonych przedsięwzięć (np. inwestycji). Trzeba też zauważyć, że w kolejnych (od 2004 r.) regulacjach dotyczących wsparcia rozwoju obszarów wiejskich, przy znacznej rozbudowie kierunków wsparcia, zwiększał się również zakres stosowania umowy jako mechanizmu organizującego wsparcie $^{20}$, co oznacza docenienie niewładczych, dialogowych form działania administracji, w tym umów administracyjnych.

Jeśli chodzi o sam model ustawowy elementów umowy o przyznaniu pomocy, to stronę podmiotową tworzą ubiegający się o jej uzyskanie (beneficjent) oraz różnego rodzaju podmioty wdrażające (Krajowy Ośrodek Wsparcia Rolnictwa, jednostki samorządu terytorialnego), będące podmiotami administrującymi. Natomiast treść umowy o przyznaniu pomocy, zawieranej

${ }^{17}$ Syntetyczne omówienie całości problematyki: A. Niewiadomski, P. Wojciechowski, P. Będźmirowska, Program rozwoju obszarów wiejskich, w: P. Czechowski (red.), Prawo rolne, s. 563-581.

${ }^{18}$ Ponadto ustawa zobowiązuje ministra rolnictwa i rozwoju wsi do regulacji każdego z działań szczegółowym rozporządzeniem wykonawczym.

${ }^{19}$ Na ten temat: S. Prutis, Dobór instrumentów prawnych stużacych wsparciu rozwoju obszarów wiejskich, ,Studia Iuridica Agraria” 2009, t. VII, s. 192-203.

${ }^{20}$ Ibidem, s. 197-198. 
na piśmie pod rygorem nieważności, ustawodawca zakreśla poprzez ustalenie swoistego minimum. Zgodnie $\mathrm{z}$ art. 36 ustawy umowa o przyznaniu pomocy „zawiera co najmniej”: 1) oznaczenie jej przedmiotu i stron; 2) określenie warunków, terminu i miejsca realizacji operacji, celu tejże operacji oraz wskaźników jego osiągnięcia; 3) określenie wysokości pomocy, warunków i terminu wypłaty środków finansowych z tytułu pomocy; 4) zobowiązanie do poddania się kontroli prowadzonej przez instytucję zarządzającą, agencję płatniczą, właściwy podmiot wdrażający, właściwą instytucję pośredniczącą, jednostkę certyfikującą, przedstawicieli Komisji Europejskiej oraz instytucji uprawnionych do przeprowadzenia kontroli; 5) określenie warunków rozwiązania umowy; 6) określenie warunków, wysokości i form stosowanych kar administracyjnych przewidzianych przepisami prawa unijnego; 7) określenie warunków i sposobu zwrotu środków finansowych, w przypadku gdy pomoc jest nienależna.

7. Ustawowa regulacja elementów podmiotowych i przedmiotowych umowy przyznania pomocy w celu realizacji PROW prowadzi do konstatacji, że umowa ta nie mieści się w typologii umów cywilnoprawnych. Podzielam stanowisko Doroty Łobos-Kotowskiej, która analizując umowę, stwierdziła: „W przypadku umowy cywilnoprawnej zawieranej w sferze administracji świadczącej wymyka się ona jednak przyjętym regułom i nie daje się bezwarunkowo i ostatecznie zakwalifikować do kategorii umów prawa cywilnego"21. Autorka szczegółowo omówiła to w monografii poświęconej tej umowie, we wnioskach której stwierdziła, że umowa przyznania pomocy jest źródłem „specyficznego stosunku obligacyjnego"; że jest cywilnoprawną formą działania administracji ${ }^{22}$. Wskazała też, że mechanizm cywilnoprawnej umowy wpisuje się w zmiany zachodzące w legislacji, a polegające na stosowaniu cywilnoprawnej metody regulacji także w zakresie wsparcia finansowego ze środków UE. Konieczne jest zatem stworzenie rozwiązania modelowego w zakresie rozdziału środków z funduszy UE; a kształt tego modelu powinien być dobrze przemyślany, z uwzględnieniem celów, jakie ustawodawca chce osiągnacéc ${ }^{23}$. Stanowisko autorki, opublikowane w 2013 r., zasługuje na aprobatę. Jednakże obecnie, po pogłębieniu swojej wiedzy na temat relacji między instytucjami prawa prywatnego i prawa publicznego, jestem zdania, że należy postawić „kropkę nad i”.

${ }^{21}$ D. Łobos-Kotowska, Umowa o przyznanie pomocy z EFRROW a inne podobne umowy, „Studia Iuridica Agraria” 2012, t. X, s. 271-278.

22 D. Łobos-Kotowska, Umowa przyznawania pomocy z Europejskiego Funduszu Rolnego na rzecz Rozwoju Obszarów Wiejskich, Warszawa 2013, s. 332 i n.

${ }^{23}$ Ibidem. 
Moja propozycja modelowa (oczywiście dyskusyjna, lecz stanowcza) polega na uznaniu, że umowa przyznania pomocy w celu realizacji PROW jest nowym typem umowy nazwanej, z tym że umowa ta, ze względu na swoją specyfikę: w zakresie treści zobowiązań (nie mieszczą się w podstawowych klasyfikacjach umów cywilnych), pełnionej funkcji (realizacja celów WPR), trybu kontroli jej wykonania oraz odrębności konstrukcyjnej od umów cywilnych (obligatoryjna forma działania podmiotów administrujących), powinna być zaliczana do kategorii umów administracyjnych o charakterze prawnorolnym.

8. Powyższa propozycja opiera się również na przyjętym modelu ochrony prawnej beneficjenta korzystającego z pomocy. Beneficjentem PROW są mieszkańcy obszarów wiejskich, głównie rolnicy, spełniający określone prawem warunki uzyskania pomocy przewidzianej w ramach poszczególnych działań. W przypadku działań, w których pomoc udzielana jest w formie decyzji administracyjnej, kontrola legalności działania administracji przebiega według reguł ogólnych - skarga na ostateczną decyzję odmowną lub bezczynność organu administracji do sądu administracyjnego. W przypadku działań, w których pomoc udzielana jest poprzez zawarcie umowy, środki ochrony prawnej beneficjenta stanowiły przez długi okres kwestię sporną. Jeśli chodzi o charakter prawny czynności poprzedzających zawarcie umowy o przyznanie pomocy, to orzecznictwo sądów administracyjnych nie było jednolite; w orzecznictwie NSA, w zakresie możliwości egzekwowania uprawnień do uzyskania pomocy przyznawanej na podstawie umowy, prezentowane były dwa stanowiska: 1) uznanie odmowy zawarcia umowy za decyzję administracyjną, zaskarżaną $\mathrm{w}$ trybie administracyjnym, 2) poszukiwanie ochrony w trybie cywilnoprawnym ${ }^{24}$. W rozstrzygnięciu ustawodawczym przyjęto trzecie rozwiązanie. Kontrowersje co do charakteru prawnego odmowy przyznania pomocy, udzielanej na podstawie umowy, zostały rozstrzygnięte przepisem art. 35 ustawy. W przypadku, gdy nie są spełnione warunki przyznania pomocy, podmiot właściwy w sprawie o przyznanie pomocy informuje podmiot ubiegający się o jej przyznanie, w formie pisemnej, o odmowie przyznania pomocy z podaniem przyczyn. W takiej sytuacji podmiotowi ubiegającemu się przysługuje prawo wniesienia do sądu administracyjnego skargi, w trybie i na zasadach określonych dla aktów i czynności, o których mowa w art. $3 \S 2$ pkt 4 ustawy - Prawo o postępowaniu przed

${ }^{24}$ Szerzej: S. Prutis, Skuteczność ochrony prawnej uprawnionych do korzystania ze środków Europejskiego Funduszu Rolnego, „Studia Iuridica Agraria” 2010, t. VIII, s. 101 i n. 
sądami administracyjnymi ${ }^{25}$. Ochrona interesu prawnego beneficjenta, ubiegającego się o uzyskanie pomocy w drodze umowy, przyjmuje zatem charakter administracyjnoprawny ${ }^{26}$. Postępowanie poprzedzające zawarcie umowy, mające na celu sprawdzenie spełnienia warunków przyznania pomocy, ma przecież postać szczególnego postępowania administracyjnego, choć z ograniczonym zastosowaniem k.p.a. Skarga na odmowę zawarcia umowy wnoszona do sądu administracyjnego nadaje sprawie charakter sprawy sądowoadministracyjnej w rozumieniu art. 2 Prawa o postępowaniu przed sądami administracyjnymi. Administracyjnoprawny model ochrony prawnej beneficjenta $\mathrm{w}$ fazie poprzedzającej zawarcie umowy odróżnia tę umowę od umowy cywilnoprawnej, co przemawia również za uznaniem jej za umowę administracyjną.

9. Jeśli chodzi o zasady wykonania zobowiązań wynikających z umowy, to są one określone przepisami ustawy oraz rozporządzenia wykonawczego regulującego sposób realizacji poszczególnych działań lub poddziałań. Stosowane są również wzory umów wydawane przez podmioty zarządzające, a swoboda stron zawierających umowę administracyjną ogranicza się do wypełnienia formularza umowy. Szczegółowo regulowany jest sposób wykonywania umowy przyznania pomocy, a zobowiązanie beneficjenta do poddania kontroli wszystkich jednostek organizacyjnych jest obligatoryjnym elementem zawieranej umowy. Wszystkie te okoliczności przemawiają za zaliczeniem umowy o przyznaniu pomocy do typu umów administracyjnych. Dla propozycji wyodrębnienia umowy administracyjnej nie stanowi przeszkody kwestia odpowiedzialności za szkody majątkowe wyrządzone nienależytym wykonaniem lub niewykonaniem takiej umowy. Zgodnie z dominującym poglądem doktryny ${ }^{27}$ odpowiedzialność odszkodowawcza jest zawsze odpowiedzialnością cywilnoprawną, ponieważ ogólne zasady rządzące określeniem odszkodowania za szkodę majątkową są takie same bez względu na to, jakie było źródło powstania tego obowiązku ${ }^{28} . \mathrm{Z}$ tego też względu - zdaniem Macieja Kalińskiego - stosunek odszkodowawczy ma zawsze charakter cywilnoprawny, a odpowiedzialność odszkodowawczą należy uznać za element odpowiedzialności cywilnej ${ }^{29}$.

${ }^{25}$ Ustawa z 30 sierpnia 2002 r. Prawo o postępowaniu przed sądami administracyjnymi (t.j. Dz. U. z 2019 r., poz. 2325).

${ }^{26}$ Szerzej: S. Prutis, Skuteczność ochrony prawnej..., s. 192-203.

27 Szerzej: S. Prutis, Instytucje podstawowe prawa prywatnego..., s. 377-385.

${ }_{28}$ M. Kaliński, Szkoda na mieniu i jej naprawienie, Warszawa 2014, s. 9 i n.

${ }^{29}$ Ibidem. Autor powołuje się także na monografię A. Szpunara, Odszkodowanie za szkodę majątkową. Szkoda na mieniu i osobie, Bydgoszcz 1998. 
Sam ustawodawca, konstruując model ustawowy umowy przyznawania pomocy, nie zajmuje wyraźnego stanowiska co do charakteru tej umowy, czego dowodem jest regulacja kwestii ważności umowy. Na podstawie art. 36 ust. 2 ustawy umowa jest nieważna w przypadkach określonych w Kodeksie cywilnym lub w przypadku sprzeczności z przepisami, o których mowa w art. 1 pkt 1, oraz przepisami wydanymi na podstawie art. 45 ust. 1 pkt 1 ustawy $^{30}$. Takie blankietowe odesłanie do Kodeksu cywilnego nie świadczy o tym, że umowa ma charakter cywilnoprawny; przeciwnie, skoro wskazuje na pomocnicze stosowanie Kodeksu cywilnego. Jest to rozwiązanie podobne do art. 300 Kodeksu pracy odsyłającego w sprawach nieunormowanych do Kodeksu cywilnego, jeśli nie jest to sprzeczne z zasadami prawa pracy. Podobnie do umowy administracyjnej należy pomocniczo stosować te rozwiązania kodeksowe, które określają uniwersalne przesłanki ważności oświadczenia woli każdej ze stron oraz warunki ważności konsensu jako istoty każdej umowy w systemie prawa.

10. Kategoria umów prawnorolnych jest wyodrębniana także spośród umów cywilnoprawnych według kryterium funkcjonalnego lub przedmiotowego. Jak wiadomo, w obszarze prawa rolnego znajdują się klasyczne instytucje należące do prawa prywatnego, mające swoje miejsce w regulacjach Kodeksu cywilnego, np. pojęcia gospodarstwa rolnego i nieruchomości rolnej, obrót takimi nieruchomościami, zniesienie współwłasności, dziedziczenie gospodarstw rolnych, umowa kontraktacji. Cywilistyczna kwalifikacja tych instytucji nie budzi wątpliwości. Jednak w prawie rolnym silnie jest zaznaczony element publicznoprawny, którego udział zwiększa się wraz z rozrastaniem się regulacji prawnorolnych Unii Europejskiej. Spośród instytucji oraz czynności prawa prywatnego do prawa rolnego zalicza się regulacje i normy ,związane z kształtowaniem przez państwo ustroju rolnego i produkcji rolnej-z punktu widzenia interesu społeczno-gospodarczego" ${ }^{31}$. Przytoczona definicja akcentuje ujęcie funkcjonalne - prawo rolne jest instrumentem polityki rolnej państwa. Profesor Budzinowski definiuje prawo rolne jako zespół norm prawnych regulujących działalność rolniczą oraz stosunki społeczne ściśle z tą działalnością związane; proponowana definicja

\footnotetext{
${ }^{30}$ Art. 1 ustawy wymienia przepisy prawa unijnego stanowiące podstawę funkcjonowania PROW, natomiast art. 45 ust. 1 stanowi podstawę wydawania wszelkich rozporządzeń wykonawczych do ustawy przez ministra do spraw rozwoju wsi, co praktycznie oznacza operowanie sankcją nieważności umowy w przypadku naruszenia każdego z wykonawczych przepisów administracyjnych.

31 Tak określali prawo rolne autorzy pierwszego podręcznika: J. Selwa, A. Stelmachowski, Prawo rolne, Warszawa 1970, s. 13.
} 
prezentuje ujęcie przedmiotowe, bowiem odwołanie się do pojęcia działalności rolniczej stanowi generalne kryterium wyodrębnienia tej gałęzi prawa ${ }^{32}$. Natomiast według Aleksandra Lichorowicza przez prawo rolne należy rozumieć zespół instytucji i rozwiązań prawnych o charakterze szczególnym, podyktowanym specyfiką rolnictwa jako odrębnego działu gospodarki, które tworzą ramy prawne (strukturalne i techniczne) działalności produkcyjnej $\mathrm{w}$ rolnictwie, jak również dla przetwarzania i obrotu produktami rolnymi ${ }^{33}$.

W niniejszych rozważaniach na temat umów przydatna będzie, ujęta instytucjonalnie, propozycja A. Lichorowicza akcentująca ,zespół instytucji i rozwiązań prawnych o charakterze szczególnym, podyktowanym specyfiką rolnictwa". Do umów prawnorolnych, będących konstrukcyjnie umowami cywilnoprawnymi, można zaliczać umowy „o charakterze szczególnym, podyktowanym specyfiką rolnictwa”. Pogłębioną analizę należy prowadzić przy uwzględnieniu odrębności dwóch segmentów ustroju rolnego. Te segmenty to: 1) układ stosunków własnościowych (i będących jego konsekwencją form organizacyjnych gospodarstw rolnych), 2) organizacja działalności produkcyjnej oraz organizacja rynków rolnych. W rozważaniach tych należy także uwzględnić historyczną zmienność celów i funkcji, zasad i programów polityki rolnej, określających kształt zastosowanych rozwiązań prawnych.

11. W kształtowaniu układu stosunków własnościowych istotne znaczenie ma regulacja prawna obrotu nieruchomościami rolnymi, w którym przez cały okres PRL obowiązywały różnego rodzaju ograniczenia. Dopiero nowela Kodeksu cywilnego z 1990 r. ${ }^{34}$ zniosła ograniczenia dotyczące obrotu ziemią, czyli nabywania nieruchomości w drodze umów. Od jej wejścia w życie nieruchomości rolne mógł nabywać każdy podmiot, a co najważniejsze - podział gospodarstwa rolnego na skutek przeniesienia własności nieruchomości rolnej lub umownego zniesienia współwłasności mógł być dokonywany bez ograniczeń. W doktrynie prawa rolnego w ocenie zmian przeważały głosy zdecydowanie negatywne; uznano bowiem, że jest to deregulacja ustawodawstwa czy „dekompozycja uregulowań dotyczących obrotu własnościowego gruntami rolnymi” ${ }^{35}$. A. Stelmachowski, oceniając okres po przełomie 1989 r., z przekąsem stwierdził, że sternicy gospodarki narodowej uważali, iż mechanizm rynkowy sam wyreguluje procesy go-

${ }^{32}$ R. Budzinowski, Problemy ogólne prawa rolnego..., s. 246.

${ }_{33}$ A. Lichorowicz, Pojęcie i przedmiot prawa rolnego, w: A. Stelmachowski (red.), Prawo rolne, Warszawa 2009, s. 27, 31.

${ }^{34}$ Ustawa z 28 lipca 1990 r. o zmianie Kodeksu cywilnego (Dz. U. Nr 55, poz. 321); weszła w życie 1 października $1990 \mathrm{r}$.

${ }^{35}$ Z. Truszkiewicz, w: P. Czechowski (red.), Prawo rolne, s. 203. 
spodarcze, stąd „dominował skrajny liberalizm”36. Politykę rolną do obrotu nieruchomościami rolnymi wprowadzono ponownie ustawą z 11 kwietnia 2003 r. o kształtowaniu ustroju rolnego ${ }^{37}$. Stanowiła ona przejaw powrotu ustawodawcy do aktywnego oddziaływania na kształtowanie się struktur rolnych. Istotna jej nowelizacja dokonana ustawą z 14 kwietnia 2016 r. spowodowała, że - zdaniem Zygmunta Truszkiewicza - „kwestia obrotu nieruchomościami rolnymi w Polsce stała się przedmiotem nie tylko regulacji prawa cywilnego, ale została dodatkowo poddana regulacji administracyjnoprawnej. Ustawodawca zdecydował się zatem na zastosowanie instrumentów znacznie głębiej ingerujących w obrót gruntami rolnymi, niż miało to miejsce przed wejściem w życie wspomnianej nowelizacji”38.

Abstrahując od oceny (często krytycznej ${ }^{39}$ ) aktualnego modelu obrotu gruntami rolnymi, powyższe przypomnienie służyć ma porównaniu umów ze sfery obrotu gruntami rolnymi, zawieranych w okresach obowiązywania poszczególnych regulacji. We wszystkich okresach i dla wszystkich rodzajów nieruchomości podstawę obrotu własnościowego stanowiła instytucja przeniesienia własności w drodze umowy o podwójnym skutku $(\text { art. } 155 \text { k.c. })^{40}$. Przeniesienie własności jest techniczno-prawnym terminem oznaczającym następcze nabycie własności każdej rzeczy na mocy umowy; a zatem umowa cywilnoprawna jest podstawą konstrukcyjną obrotu gruntami (nieruchomościami). Jednakże obrót gruntami rolnymi w postaci stricte cywilistycznej miał miejsce jedynie w latach 1990-2003, gdy przeniesienie własności służyło realizacji i ochronie wyłącznie prywatnych interesów stron $^{41}$ zawierających umowę. W pozostałych okresach regulacja prawna obrotu gruntami rolnymi, realizując postulaty polityki rolnej w zakresie aktywnego kształtowania pożądanego modelu ustroju rolnego, określała przesłanki, warunki i cele obrotu zgodne $\mathrm{z}$ interesem publicznym. I ta funkcja publiczna, jaką jest użycie instrumentu cywilnoprawnego do realizacji celów polityki rolnej, powoduje, że obrót gruntami rolnymi należy zaliczyć

${ }^{36}$ A. Stelmachowski, w: A. Stelmachowski (red.), Prawo rolne, s. 38-41.

37 Tekst pierwotny ustawy: Dz. U. Nr 64, poz. 592, aktualny tekst jednolity: Dz. U. z 2019 r., poz. 1362.

${ }^{38}$ Z. Truszkiewicz, w: P. Czechowski (red.), Prawo rolne, s. 228.

39 S. Prutis, Status prawny rodzinnego gospodarstwa rolnego w polskim prawie rolnym (ocena stanu regulacji), w: P. Litwiniuk (red.), Prawne mechanizmy wspierania i ochrony rodzinnego $w$ Polsce i innych państwach UE, Warszawa 2015, s. 11 i n. (i powołana tam literatura).

${ }^{40}$ A. Stelmachowski, Nabycie i utrata własności, w: T. Dybowski (red.), System Prawa Prywatnego, t. 3: Prawo rzeczowe, Warszawa 2003, s. 309.

${ }^{41} \mathrm{~W}$ prawie rzymskim kryterium interesu decydowało o podziale na prawo prywatne i publiczne. Ius publicum służyło ochronie dobra całej zbiorowości, zaś ius privatum chroniło interesy poszczególnych osób (D.1.1.1.2.). 
do rozwiązań prawnych nazywanych przez A. Lichorowicza rozwiązaniami o charakterze szczególnym, podyktowanym specyfiką rolnictwa. Przeniesienie własności nieruchomości rolnej jest zatem konstrukcyjnie umową cywilnoprawną (zawierana jest pomiędzy równorzędnymi podmiotami), zaś funkcjonalnie powinna być zaliczana do umów prawnorolnych, bo jednocześnie zapewnia realizację celów publicznych w dziedzinie rolnictwa. Patrząc z obecnej perspektywy na instytucje prawne obrotu ziemią, uprawnione jest chyba stwierdzenie, że w sytuacji ingerencji polityki rolnej w sferę obrotu przeniesienie własności nieruchomości rolnej przestaje spełniać standardy umowy prawa prywatnego.

12. Podobna sytuacja ma miejsce również $\mathrm{w}$ drugim segmencie ustroju rolnego, jakim jest organizacja produkcji rolnej oraz organizacja rynku rolnego. Odnosząc się do czasów socjalistycznej gospodarki planowej, można wskazać na grupę umów stymulujących poziom produkcji rolniczej. Organizacji skupu produktów rolnych służyła wówczas kontraktacja jako podstawowa forma skupu. Powiązania umowne między rolnikami indywidualnymi a jednostkami gospodarki uspołecznionej działającymi w sferach: usług produkcyjnych dla rolnictwa, produkcji rolnej oraz skupu produktów zostały nazwane przez Wiktora Pawlaka ,umowami o aspekcie rolnym”. Jego zdaniem aspekt rolny tych umów ,przejawia się w ich celu gospodarczym, związanym w różnym zakresie z realizowanym procesem produkcji rolnej”"42. Do umów tych autor zaliczył „przede wszystkim” (co oznacza, że wyliczenie nie miało charakteru wyczerpującego): umowę o usługi produkcyjne w rolnictwie, umowę kontraktacji oraz umowę o kooperacji produkcyjnej w rolnictwie ${ }^{43}$; ze swej strony do umów o aspekcie rolnym zaliczyłbym również umowę o utworzeniu zespołów rolników indywidualnych w celu wspólnego prowadzenia gospodarstwa specjalistycznego ${ }^{44}$. Podstawę zawarcia tych umów stanowiły przepisy prawa cywilnego regulujące umowę o świadczenie usług (art. 750 k.c.), umowę kontraktacji (art. 613-626 k.c.) czy - w przypadku zespołu rolników - umowę spółki cywilnej (art. 860-875 k.c.). Jedynie umowa kooperacji międzysektorowej była trudna do zakwalifikowania. Według Józefa Paliwody „to umowa nazwana, długoterminowa, stopniowo integrująca działalność gospodarczą uczestniczących w niej stron, unormowana poza kodeksem cywilnym. Tak określona umowa występuje tylko

42 W. Pawlak, Prawo rolne, Warszawa - Poznań 1981, s. 278.

${ }^{43}$ Szerzej na temat tych umów: rozdział 12 tegoż opracowania zatytułowany Umowy o aspekcie rolnym, s. 278-296.

${ }^{44}$ Szerzej: S. Prutis, Zespoty rolników indywidualnych (Problemy organizacyjno-prawne), Warszawa 1980. 
w rolnictwie"45. Treść tych regulacji nie pozostawia wątpliwości, iż funkcją tych umów była realizacja interesu społecznego, wyrażanego w programach polityki rolnej, przez jednostki uspołecznione, będące stronami tych umów. Ówcześni komentatorzy Kodeksu cywilnego nie mieli wątpliwości, że kontraktacja, która „stała się stopniowo narzędziem cywilistycznej metody regulacji przez państwo obrotu towarowego [...] jest planowym systemem organizacji produkcji rolno-hodowlanej oraz skupu produktów rolnych"46.; kontraktacja nazywana była najniższym poziomem gospodarki planowej. A zatem zaliczenie umowy kontraktacji, będącej konstrukcyjnie umową cywilnoprawną, do umów prawnorolnych w ujęciu funkcjonalnym miało swoje uzasadnienie.

13. Oczywiście regulacje te, będące instrumentem ówczesnej polityki rolnej i gospodarki planowej, przeminęły wraz z wprowadzeniem społecznej gospodarki rynkowej. Przetrwała wszakże regulowana przepisami Kodeksu cywilnego konstrukcja umowy kontraktacji, choć oczywiście nowelą Kodeksu cywilnego dokonano koniecznych zmian ${ }^{47}$. Najważniejszą z nich jest zmiana oznaczenia strony kontraktującej; przed nowelizacją mogła to być tylko jednostka gospodarki uspołecznionej, po niej zaś - każdy przedsiębiorca zamierzający nabyć produkty rolne, wytworzone przez producenta prowadzącego gospodarstwo rolne.

Elementy regulacji kodeksowej umowy kontraktacji pozwalają na twierdzenie, że jest to nazwana umowa cywilnoprawna, będąca instrumentem gospodarki rynkowej, skonstruowanym wszakże w sposób specyficzny, od strony podmiotowej i przedmiotowej, dla potrzeb rolnictwa. Jedną ze stron musi być producent rolny, a przedmiotem świadczenia - produkty rolne; ponadto przedmiot umowy wykracza poza typową dla prawa cywilnego sferę wymiany dóbr i usług, obejmując także wytworzenie produktu, a więc sferę produkcji rolnej, i to z przyznaniem kontraktującemu uprawnień do nadzoru i kontroli nad wykonywaniem umowy kontraktacji przez producenta. Na tym tle w praktyce gospodarczej lat 90. pojawiło się rozróżnienie kontraktacji produkcyjnej i handlowej. Kontraktacja handlowa miała za cel jedynie nabycie finalnego produktu rolnego o określonych cechach i parametrach, co ma miejsce przy produktach masowych

45 J. Paliwoda, Problemy prawne kooperacji produkcyjnej w rolnictwie, Warszawa 1979, s. 209.

${ }^{46}$ F. Błahuta, Z. Resich, J. Ignatowicz, Kodeks cywilny - Komentarz, t. 2, Warszawa 1972, s. 1348.

${ }^{47}$ Przepisy art. 613-626 k.c. znowelizowane przepisami ustawy z 28 lipca 1990 r. o zmianie ustawy - Kodeks cywilny (Dz. U. Nr 55, poz. 321). 
(zboża, żywiec wieprzowy). Bliższa współpraca produkcyjna zachowała się jedynie w zakresie tradycyjnie reglamentowanej kontraktacji takich produktów jak buraki cukrowe ${ }^{48}$ czy tytoń, a także w sytuacji, gdy obie strony są szczególnie zainteresowane zbyciem i pozyskaniem produktu wysokiej jakości (kwalifikowany materiał siewny). Obraz kontraktacji w przedziale czasowym między polityką rolną gospodarki planowej a zastosowaniem kontraktacji w organizacjach branżowych Wspólnego Rynku UE jest zatem zróżnicowany. Zdaniem Jerzego Rajskiego występuje tu ogólniejsza prawidłowość: „ilekroć produkcja danego artykułu rolnego podlega reglamentacji, pojawia się umowa kontraktacji jako szczególnie przydatny instrument pozyskiwania danego produktu rolnego. [...] Umowy kontraktacji były i są zawierane również $\mathrm{w}$ razie braku takiej regulacji, ważna jest wszakże konstatacja, że regulacja rynku w zakresie określonego produktu nieuchronnie pociąga za sobą wykorzystanie kontraktacji jako ogniwa tej regulacji” ${ }^{49}$. Z taką sytuacją mamy do czynienia od czasu wejścia do Unii Europejskiej, gdy realizacji celów Wspólnej Polityki Rolnej podporządkowano organizację handlu produktami rolnymi. W jej ramach wyodrębniono, w ujęciu przedmiotowym, wspólną organizację rynków towarowych o charakterze branżowym, które poddano regulacji interwencyjnej. Zdaniem specjalistów: „To właśnie poprzez system organizacyjny rynków rolnych realizowana jest polityka interwencji Unii Europejskiej w sferze wspomagania producentów i przetwórstwa rolno-spożywczego" 50 . Umowy cywilnoprawne stosowane w organizacji branżowych, wspólnych rynków danego produktu rolnego należy zaliczać - w płaszczyźnie funkcjonalnej - do umów prawnorolnych.

14. Zgłoszona propozycja wyodrębnienia i posługiwania się kategorią „umów prawnorolnych" ma charakter konwencjonalnego ujęcia, które choć jest oczywiście dyskusyjne, to ma znaczenie porządkujące dla objaśnienia relacji pomiędzy mechanizmami prawa prywatnego i publicznego, a także dla podkreślenia integralności prawa rolnego jako odrębnej gałęzi prawa.

Prowadzone przeze mnie badania porównawcze nad instytucjami prawa prywatnego i publicznego dały podstawę twierdzeniu, że instytucje prawa prywatnego pozostają $\mathrm{w}$ swoistej opozycji do regulacji prawa publicznego, co jest konsekwencją przeciwstawności cech konstrukcyjnych

${ }^{48}$ Ustawa z 21 czerwca 2001 r. o organizacji rynku cukru (Dz. U. Nr 76, poz. 810 ze zm.).

49 J. Rajski, Kontraktacja, w: J. Rajski (red.), System Prawa Prywatnego, t. 7: Prawo zobowiązań - część szczegółowa, Warszawa 2011, System informacji prawnej Legalis, s. 8.

${ }^{50}$ P. Czechowski, A. Niewiadomski, Europejskie rynki rolne, w: P. Czechowski (red.), Prawo rolne, s. 523, 539 . 
obu metod regulacji prawnej ${ }^{51}$. Oznacza to, że konstrukcje prawne stosowane $\mathrm{w}$ prawie prywatnym mają swoje odpowiedniki na gruncie prawa publicznego, i odwrotnie. Na podobieństwo natury funkcjonalnej i zwrotne relacje między obiema metodami zwracają uwagę także administratywiści. Znamienna jest konstatacja Marka Wierzbowskiego i Aleksandry Wiktorowskiej: „Pojęcie prawnej formy działania administracji na gruncie prawa administracyjnego jest odpowiednikiem pojęcia czynności prawnej na gruncie prawa cywilnego" 52 . Moim zdaniem umowa administracyjna, jako prawna forma działania administracji, jest właśnie odpowiednikiem umowy cywilnoprawnej jako czynności prawnej prawa prywatnego. Ten status „odpowiednika” wynika z różnic konstrukcyjnych między obiema umowami, dlatego wszelkie doktrynalne klasyfikacje umów cywilnoprawnych mogą być przymierzane do umów administracyjnych co najwyżej „odpowiednio". Na przykładzie umów o przyznawaniu pomocy na realizację PROW można stwierdzić, że odmienność umów administracyjnych wyraża się w celu bądź przyczynie prawnej zawarcia umowy. Podmiot administrujący i rolnik zawierają umowę w sprawie wspólnej realizacji celu polityki rolnej, co można porównać jedynie z celem umowy spółki cywilnej Kodeksu cywilnego, podczas gdy większość umów cywilnych to umowy wzajemne, czyli wymiana ekwiwalentnych świadczeń, czego nie ma w umowach administracyjnych.

Propozycja wprowadzenia kategorii pojęciowej, jaką są ,umowy prawnorolne", obejmującej swoim zakresem całość umów, zarówno cywilnych, jak i administracyjnych, ma na celu podkreślenie, że to właśnie prawo rolne jest dziedziną, w której stosowane są obie kategorie umów. I nie chodzi tu jedynie o dywagacje teoretyczne, ale także o normatywną i empiryczną rzeczywistość. Dlatego umowy prawnorolne mogą być jedną z instytucji prawnych świadczących o potrzebie integralnego badania, a więc o potrzebie wyodrębnienia prawa rolnego.

\section{BIBLIOGRAFIA}

Błahuta F., Resich Z., Ignatowicz J. (1972), Kodeks cywilny - Komentarz, t. 2, Warszawa. Boć J. (2013), Działalność konsensualna (dwustronna i wielostronna), w: A. Błaś, J. Boć, M. Stahl, K.M. Ziemski, System Prawa Administracyjnego, t. 5: Prawne formy działania administracji, Warszawa.

Budzinowski R. (2008), Problemy ogólne prawa rolnego. Przemiany podstaw legislacyjnych i koncepcji doktrynalnych, Poznań.

${ }^{51}$ S. Prutis, Instytucje podstawowe prawa prywatnego..., s. 62-66.

${ }_{52}$ M. Wierzbowski, A. Wiktorowska, Prawo administracyjne, Warszawa 2003, s. 265. 
Budzinowski R. (2019), Prawo rolne i inne dziedziny prawa, w: P. Czechowski (red.), Prawo rolne, Warszawa.

Czechowski P., Niewiadomski A. (2019), Europejskie rynki rolne, w: P. Czechowski (red.), Prawo rolne, Warszawa.

Kaliński M. (2014), Szkoda na mieniu i jej naprawienie, Warszawa.

Lichorowicz A. (2009), Pojęcie i przedmiot prawa rolnego, w: A. Stelmachowski (red.), Prawo rolne, Warszawa.

Łobos-Kotowska D. (2012), Umowa o przyznanie pomocy z EFRROW a inne podobne umowy, „Studia Iuridica Agraria” t. X.

Łobos-Kotowska D. (2013), Umowa przyznawania pomocy z Europejskiego Funduszu Rolnego na rzecz Rozwoju Obszarów Wiejskich, Warszawa.

Milanowska D. (2015), Wspólna Polityka Rolna, w: S. Prutis (red.), Wielka Encyklopedia Prawa, t. VIII: Prawo rolne i żywnościowe, Warszawa.

Niewiadomski A., Wojciechowski P., Będźmirowska P. (2019), Program rozwoju obszarów wiejskich, w: P. Czechowski (red.), Prawo rolne, Warszawa.

Paliwoda J. (1979), Problemy prawne kooperacji produkcyjnej w rolnictwie, Warszawa.

Pawlak W. (1980), Prawo rolne, Warszawa - Poznań.

Prutis S. (1980), Zespoły rolników indywidualnych (Problemy organizacyjno-prawne), Warszawa.

Prutis S. (2009). Dobór instrumentów prawnych slużących wsparciu rozwoju obszarów wiejskich, „Studia Iuridica Agraria” t. VII.

Prutis S. (2010), Skuteczność ochrony prawnej uprawnionych do korzystania ze środków Europejskiego Funduszu Rolnego, „Studia Iuridica Agraria” t. VIII.

Prutis S. (2015), Status prawny rodzinnego gospodarstwa rolnego w polskim prawie rolnym (ocena stanu regulacji), w: P. Litwiniuk (red.), Prawne mechanizmy wspierania i ochrony rodzinnego $w$ Polsce i innych państwach UE, Warszawa.

Prutis S. (2018), Instytucje podstawowe prawa prywatnego (w opozycji do regulacji prawa publicznego), Białystok.

Prutis S. (2021), Typologia umów stosowanych poza sfera prawa prywatnego, w: A. Niewiadomski, K. Marciniuk, P. Litwiniuk (red.), Z zagadnień systemu prawa. Księga Jubileuszowa Profesora Pawła Czechowskiego, Warszawa.

Rajski J. (2011), Kontraktacja, w: J. Rajski (red.), System Prawa Prywatnego, t. 7: Prawo zobowiazań - część szczegółowa, Warszawa.

Selwa J., Stelmachowski A. (1970), Prawo rolne, Warszawa.

Starościak J. (1957), Prawne formy działania administracji, Warszawa.

Starościak J. (1977), Prawo administracyjne, Warszawa.

Stelmachowski A. (1998), Zarys teorii prawa cywilnego, Warszawa.

Stelmachowski A. (2003), Nabycie i utrata własności, w: T. Dybowski (red.), System Prawa Prywatnego, t. 3: Prawo rzeczowe, Warszawa.

Stelmachowski A. (red.) (2009), Prawo rolne, Warszawa.

Szpunar A. (1998), Odszkodowanie za szkodę majątkową. Szkoda na mieniu i osobie, Bydgoszcz.

Truszkiewicz Z. (2019), Kształtowanie stosunków własnościowych w rolnictwie, w: P. Czechowski (red.), Prawo rolne, Warszawa.

Wierzbowski M., Wiktorowska A. (2003), Prawo administracyjne, Warszawa. 


\title{
AGRICULTURAL LEGAL AGREEMENTS
}

\author{
Summary
}

Distinguishing the conceptual category of "agricultural legal agreements" fulfills the ordering function in doctrinal approaches which concern the mechanism of agreement (consensus) in our legal system. I propose to use the term "agricultural legal agreements" to define all consensual legal actions that serve to implement the objectives of agricultural policy (the functional aspect), and have a nature and construction of civil-law contracts or a construction of administrative contracts that are an obligatory form of action for the administering entity. An administrative contract, as a legal form of action of an administrative body, is a specific equivalent of a civil law contract - an action in private law - taken on the grounds of public law regulations. This "counterpart" status results from structural differences between both contracts, therefore all doctrinal classifications of civil law contracts can be applied to administrative contracts, according to their "appropriateness" at best. Agricultural law is that branch of law which in its regulatory function uses both the mechanism of civil law and administrative contracts. Therefore, there is a need for an integrated research on legal contracts in agriculture, which unequivocally speaks for the need for keeping agricultural law separate.

Keywords: private law, public law, agricultural law, civil-law contract, administrative contract, agricultural legal agreement

\section{DEI CONTRATTI DI DIRITTO AGRARIO}

\section{Riassunto}

Distinguere la categoria concettuale di "umowy prawnorolne" (contratti di diritto agrario) svolge una funzione ordinativa negli approcci dottrinali, i quali riguardano il meccanismo del contratto (accordo), nel nostro ordinamento giuridico. Con il termine "contratti di diritto agrario" propongo di chiamare tutti i negozi giuridici consensuali, i quali sono volti a raggiungere gli obiettivi della politica agricola (aspetto funzionale), e il cui carattere e la cui costruzione sono quelli dei contratti di diritto civile oppure dei contratti amministrativi, i quali, a loro volta, sono una forma obbligatoria di funzionamento dell'ente amministrativo. Un contratto amministrativo, in quanto forma giuridica di attività amministrativa, è un particolare equivalente di un contratto di diritto civile - di un negozio di diritto privato - sullo sfondo delle regolazioni di diritto pubblico. Lo status di "equivalente" è dovuto alle differenze strutturali tra i due contratti, pertanto tutte le eventuali classificazioni dottrinali dei contratti di diritto civile possono essere rapportate a quelli amministrativi, al massimo "rispettivamente". Il diritto agrario è quella branca del diritto che nella sua funzione di regolazione utilizza sia il meccanismo dei contratti di diritto civile sia quello dei contratti amministrativi. Per cui è opportuno svolgere una ricerca integrata sui contratti di diritto agrario, il che va decisamente a favore della necessità di mantenere il suo carattere distinto.

Parole chiave: diritto privato, diritto pubblico, diritto agrario, contratto di diritto civile, contratto amministrativo, contratto di diritto agrario 